\title{
AUDIENS DALAM PERIKLANAN: SEBAGAI TARGET MARKET
}

Oleh

\section{Tengku Walisyah}

\begin{abstract}
Abstrak
Dalam periklanan audiens berperan sebagai target yang akan disasar oleh pesan periklanan. Istilah lainnya adalah target market. Beberapa tahapan dilalui untuk menentukan audiens sebagai target market dalam periklanan. Upaya ini digunakan untuk mempermudah menargetkan audiens ke dalam unit yang lebih kecil dimana tadinya merupakan heterogenitas. Melalui segmentasi audiens dibagi ke beberapa kategori-kategori tertentu untuk memperoleh target market yang tepat.
\end{abstract}

Kata Kunci: audiens, target market, periklanan, segmentasi, iklan

\section{PENDAHULUAN}

Audiens merupakan unsur yang esensial dalam ranah komunikasi khususnya dalam lingkup komunikasi massa. Sekaligus memainkan peranan penting dalam berlangsungnya sebuah proses komunikasi. Audiens menjadi sasaran/objek kemana pesan ditransferkan dalam memenuhi upaya tersebut. Ketika distribusi pesan disalurkan dari komunikator yang bertindak selaku sumber atau si pengirim pesan maka selanjutnya audiens lah yang menangkap sinyal berbentuk pesan yang ditujukan tadi. Bisa dipastikan jika tidak ada audiens, maka urutan proses tersebut berhenti hanya sampai pada unsur pesan saja, tidak bisa dilanjutkan sampai pada tahapan berikutnya. Pesan pun tidak dapat dioper.

Istilah audiens lebih dikenal dalam kajian komunikasi massa sementara komunikan sebagai representasi dalam fokus utamanya yatu ilmu komunikasi. Keduanya memiliki fungsi atau jabatan yang sama namun lingkup keduanya berbeda. Komunikan merujuk pada objek yang luas secara umum sesuai dengan ranah disiplin ilmu komunikasi yang menaunginya. Sementara audiens berarti 
spesifik menunjukkan objek/sasaran tertentu sama halnya dengan kajian komunikasi massa. Sekaligus menandakan bahwa dalam proses pengiriman pesan tersebut menggunakan bantuan media massa. Berarti audiens adalah komunikan yang mendapatkan pesan melalui media massa.

Komunikasi massa sebagaimana dipaparkan oleh John Vivian mempunyai ciri khas yaitu memiliki kemampuan menjangkau ribuan, atau bahkan jutaan orang melalui medium massa seperti televisi atau koran. Dia juga mendefinisikan komunikasi massa sebagai proses penggunaan medium massa untuk mengirim pesan kepada audiens yang luas untuk tujuan memberi informasi, menghibur, atau membujuk. $^{1}$

Lebih lanjut John Vivian menuturkan bahwa dalam banyak hal komunikasi massa dan bentuk komunikasi lainnya memiliki kesamaan yaitu seseorang membuat pesan (pada dasarnya adalah tindakan intrapersonal atau dari dalam diri seseorang) kemudian dikodekan dalam kode umum seperti bahasa selanjutnya ditransmisikan kepada orang lain dimana orang yang menerima pesan itu menguraikannya dan menginternalisasikannya. Dalam hal lain, komunikasi massa merupakan bentuk yang berbeda. Pesan disusun secara efektif untuk ribuan orang dengan latar belakang dan kepentingan yang berbeda-beda sehingga membutuhkan keahlian yang berbeda dengan sekedar bicara dengan teman. Maka disini pesan yang disusun sifatnya lebih kompleks karena harus menggunakan suatu sarana misalkan saja percetakan, kamera atau perekam. ${ }^{2}$

Senada dengan hal tersebut Alo Liliweri mendefinisikan bahwa komunikasi massa adalah bentuk komunikasi yang menggunakan saluran (media) untuk menghubungkan komunikator dengan komunikan secara massal, berjumlah banyak, bertempat tinggal jauh, sangat heterogen, dan menimbulkan efek-efek tertentu. Komunikan dalam komunikasi massa disini juga disebutnya sebagai sasaran penerima. ${ }^{3}$

\footnotetext{
${ }^{1}$ John Vivian, Teori Komunikasi Massa: Edisi Kedelapan (Jakarta: Kencana, 2008), hlm.
} 450.

${ }^{2}$ Ibid, hlm. 450-451.

${ }_{3}^{3}$ Alo Liliweri, Komunikasi Serba Ada Serba Makna (Jakarta: Kencana, 2011), hlm. 874. 
Dalam komponen komunikasi massa sebagaimana dipaparkan oleh John Vivian menunjukkan adanya istilah audiens. ${ }^{4}$ Dimana istilah audiens dalam komunikasi massa disebut sebagai sasaran penerima pesan massa. Sama halnya dengan periklanan yang juga menggunakan istilah tersebut dimana orang yang mendapatkan pesan periklanan disebut juga sebagai audiens. Istilah lainnya adalah khalayak, target sasaran, dan sebagainya.

Periklanan juga merupakan praktek komunikasi. Dalam proses penyampaian pesannya sama dengan kegiatan komunikasi. Dimana komunikator selaku sumber mengirimkan pesan kepada sasaran atau objek penerima pesan yang disebut sebagai komunikan atau khalayak istilah lainnya juga audiens. Hanya saja metode komunikasi yang dilancarkan berbeda. Komunikasi menggunakan metode yang beragam bisa informatif, edukatif, dan sebagainya. Sementara periklanan hanya menggunakanan metode persuasif saja. ${ }^{5}$ Pesan yang ditransfer juga tak sama, pesan periklanan memuat informasi tertentu yaitu tentang produk/jasa/ide yang ditawarkan. Sedangkan dalam komunikasi pesan mengandung banyak hal, tidak tertentu, bahkan tidak terbatas. Dari sini terlihat bahwa periklanan merupakan bagian dari ranah komunikasi.

Apa yang dipaparkan oleh John Vivian dalam komponen komunikasi massa juga semakin menegaskan posisi periklanan dalam lingkup komunikasi khususnya komunikasi massa. Lebih jauh John Vivian menguraikan dalam komponen komunikasi massa bahwa pesan massa salah satunya berisi iklan billboard. Pada prakteknya periklanan membutuhkan media massa dalam hal ini yaitu billboard untuk menjangkau audiens sebagai sasaran kemana pesan periklanan ditujukan. Meskipun dalam periklanan tidak selamanya menggunakan media ini saja pada saat pesan iklan itu dilancarkan. Media massa yang lain seperti televisi, surat kabar, majalah, dan sebagainya juga digunakan untuk menyampaikan pesan iklan tersebut. Namun, media billboard adalah media

\footnotetext{
${ }^{4}$ Data Komponen Komunikasi Massa bisa dirujuk di dalam John Vivian, Teori..., hlm. 451-454.

${ }^{5}$ Untuk data metode komunikasi yang dilancarkan ketika komunikasi berlangsung lihat sumber: Onong Uchjana Effendy, Ilmu Komunikasi: Teori dan Praktek (Bandung: PT Remaja Rosdakarya, 2013), hlm. 35.
} 
tersendiri atau media khusus yang hanya digunakan untuk menyampaikan pesan iklan. Berbeda dengan media massa lainnya yang lebih luas kegunaannya.

Periklanan adalah bagian dari kegiatan komunikasi yang spesifik dan menggunakan media massa juga ditekankan oleh O'Guin, Allen, dan Semenik sebagaimana dijelaskan oleh Idi Subandy Ibrahim menyimpulkan bahwa suatu komunikasi bisa diklasifikasikan sebagai iklan, bila memenuhi kriteria berikut: (1) komunikasi itu haruslah dengan bayaran; (2) komunikasi itu haruslah disampaikan ke khalayak via media massa; (3) komunikasi itu haruslah menjadi upaya persuasi atau membujuk. ${ }^{6}$

Dari pemaparan O'Guin, Allen, dan Semenik tampak bahwa periklanan merupakan bagian dari komunikasi atau dengan kata lain periklanan adalah manifestasi dari kegiatan ataupun upaya yang dilancarkan melalui komunikasi. Komunikasi yang dimaksud menunjukkan bahwa periklanan adalah bagian dari komunikasi massa. Sekaligus semakin mempertegas kalau periklanan itu dalam wilayah komunikasi massa. Ditandai dengan hadirnya media massa dalam menyampaikan pesan yang dimaksud. Dari kriteria yang telah diberikan tadi juga tampak bahwa metode komunikasi yang dipakai dalam periklanan adalah persuasif.

Istilah iklan sendiri dimana sebagai kata dasar dari periklanan adalah suatu upaya untuk membujuk melalui media dengan membayar. Tiga kata kunci dari definisi ini yang menjadi ciri umum setiap produk iklan yaitu membujuk, media massa, dan membayar. Definisi ini cukup menjelaskan bahwa iklan adalah komunikasi yang dibayar (paid communication) oleh sebuah perusahaan atau organisasi yang ingin informasinya disebarkan melalui media. Dalam bahasa iklan perusahaan atau organisasi yang membayar untuk iklan disebut klien atau sponsor. ${ }^{7}$ Informasi yang dimaksud jelas mengenai suatu produk, jasa atau bahkan sampai kepada ide sekalipun.

Otto Klepper dalam Rendra Widyatama menjelaskan asal muasal istilah iklan yang disebut dengan advertsising dimana awalnya berasal dari bahasa latin

\footnotetext{
${ }^{6}$ Lihat sumber Idi Subandy Ibrahim, Kecerdasan Komunikasi (Bandung: Simbiosa Rekatama Media, 2007), hlm. 128.

${ }^{7}$ O'Guinn, Allen, dan Semenik dalam Idi Subandy Ibrahim, Kecerdasan..., hlm. 128.
} 
yaitu ad-vere yang artinya mengoperkan pikiran dan gagasan kepada pihak lain. Secara sederhana definisi ini juga semakin memperjelas hubungan periklanan dengan ilmu komunikasi. Sekaligus menandakan bahwa periklanan adalah komunikasi. Sebagaimana terlihat dalam salah satu definisi komunikasi yaitu komunikasi adalah mengoperkan pesan dari satu pihak kepada pihak lain baik melalui lisan, media cetak, radio, televisi, komputer, media luar ruang, dan sebagainya. ${ }^{8}$

\section{Audiens dalam Periklanan}

Onong Uchjana Effendy menjelaskan bahwa audiens merupakan kumpulan anggota masyarakat yang terlibat dalam proses komunikasi massa sebagai sasaran yang dituju bersifat heterogen. Dalam arti keberadaannya berpencar-pencar, tidak saling mengenal dan tidak memiliki kontak pribadi. Ditambah lagi berbeda dalam berbagai hal seperti jenis kelamin, usia, agama, ideologi, pekerjaan, pendidikan, pengalaman, kebudayaan, pandangan hidup, keinginan, cita-cita, dan sebagainya. Perbedaan inilah yang disebutnya sebagai heterogenitas. ${ }^{9}$

Heterogenitas audiens menjadi tantangan besar bagi para pengelola media massa untuk menyebarluaskan pesan. Setiap individu dari audiens menghendaki agar keinginannya dipenuhi, sementara mereka terdiri dari beragam kategori. Tidaklah memungkinkan bagi para pengelola media massa untuk memenuhi keinginan mereka. Ini adalah pilihan yang sulit. Satu-satunya cara untuk bisa memudahkannya adalah dengan mengelompokkan mereka kedalam beberapa unsur yang sesuai. Mereka dibedakan berdasarkan jenis kelamin, usia, agama, pekerjaan, pendidikan, kebudayaan, kesenangan (hobby), dan sebagainya. ${ }^{10}$

Heterogenitas audiens menimbulkan upaya untuk mengelompokkan mereka ke dalam beberapa kategori. Kategori yang memisahkan audiens ke dalam beberapa kelompok disebut dengan istilah segmentasi. Hal ini ditujukan untuk

\footnotetext{
${ }^{8}$ Perhatikan sumber Rendra Widyatama, Pengantar Periklanan (Yogyakarta: Pustaka
} Book Publisher, 2009), hlm. 13.

${ }_{9}^{9}$ Onong Uchjana Effendy, Ilmu..., hlm. 25.

${ }^{10}$ Ibid. 
memberi kemudahan dalam memetakan setiap bagian yang ingin dimasuki oleh pihak produsen. Segmentasi didefinisikan sebagai suatu proses membagi audiens ke dalam beberapa sub atau bagian audiens yang berbeda, dengan kebutuhan atau karakteristik yang sama, dan memilih satu segmen atau lebih untuk disasar dengan bauran kegiatan pemasaran yang berbeda. ${ }^{11}$

Menurut Sandra Moriarty, Nancy Mitchell, dan William Wells agar iklan lebih menarik, relevan, dan mendapat perhatian, iklan harus relevan dengan minat audiens. Memahami konsumen baik itu keinginannya, minatnya, dan keadaan mentalnya adalah langkah pertama dalam mengidentifikasi sasaran yang logis untuk pesan brand. ${ }^{12}$ Sehingga untuk memudahkan upaya ini dilakukan dengan jalan segmentasi. Segmentasi atau segmenting berarti membagi audiens menjadi kelompok-kelompok orang yang memiliki karakteristik yang sama.

Lebih jauh Sandra Moriarty, dkk menjelaskan bahwa ide dibalik segmentasi adalah kelompok orang yang dibidik pemasar akan didefinisikan berdasarkan karakteristik kunci, yaitu biasanya demografis dan psikografis dan karakteristik ini membuat mereka tampak lebih mirip. Karakteristik ini juga akan mendefinisikan bagaimana mereka berbeda dari kelompok lain yang mungkin ada atau tidak ada di dalam pasar untuk produk. ${ }^{13}$

Segmentasi atau pembagian audiens berkaitan erat dengan content media massa. Ketika audiens sudah dikelompokkan sedemikian rupa, maka content media massa dikemas dan ditujukan untuk masing-masing kategori di dalam segmentasi tersebut. Dengan kata lain content media massa bisa beragam/bervariasi tergantung pemilihan segmentasinya.

Umumnya media massa seperti televisi, radio, surat kabar, majalah, dan sejenisnya memiliki beragam content di dalamnya. Bisa program anak-anak, remaja, dewasa, wanita, laki-laki dan sebagainya. Content dari kategori program ini berarti mengarah kepada audiens yang beragam sehingga segmentasinya juga

\footnotetext{
${ }^{11}$ Irham Fahmi, Perilaku Konsumen: Teori dan Aplikasi (Bandung: Alfabeta, 2016), hlm. 46.

${ }^{12}$ Sandra Moriarty, Nancy Mitchell, dan William Wells, Advertising: Edisi Kedelapan (Jakarta: Kencana, 2011), hlm. 189.

${ }^{13}$ Ibid.
} 
beragam. Namun adakalanya media massa tersebut dari segi contentnya memilih fokus hanya kepada satu segmentasi saja misalkan majalah Trubus fokus hanya berbicara mengenai tumbuh-tumbuhan, tanaman serta berkaitan dengan perkebunan/pertanian. Lain lagi majalah Femina yang lebih memilih wanita sebagai bahasan utama setiap isi lembaran majalahnya. Tabloid Pulsa juga tersegmentasi khusus mengupas tuntas segala hal tentang gadget mulai dari Hp, notebook, tablet, dan semacamnya.

Pada media televisi juga ada kalanya sebagian fokus terhadap satu segmen mengejar audiens yang senang dengan suatu kategori yang disajikan seperti TVOne, MetroTV, Spacetoon, MTV, Commercial TV seperti QVC, Home Shopping Network, dan ShopTV dari Kanada ${ }^{14}$ dan yang lain. Baik TVOne maupun MetroTV sama-sama mengagendakan berita dalam setiap program acaranya. Sementara Spacetoon lebih memilih fokus untuk audiens di kalangan anak-anak. Program acara MTV mayoritas adalah musik atau lagu-lagu sesuai dengan kepanjangannya Music Television. Dan sederet Commercial TV itu memilih fokus untuk menayangkan pesan-pesan produk/jasa. Ada juga yang tersegmentasi dengan Islam misalkan Rodja TV lebih menekankan khusus tayangan/acara Islami saja dengan menonjolkan Al-Qur'an sebagai kajian utamanya.

Media massa yang contentnya bervariasi, masing-masing program akan memiliki segmentasi tertentu sesuai kategori audiens yang telah dikelompokkan sebelumnya. Biasanya segmentasi audiens pada program tersebut hampir memenuhi seluruh kategori yang ada. Untuk media massa televisi misalnya segmentasi pada satu channelnya saja umumnya hampir lengkap menayangkan segmentasi untuk segala kelompok audiens. Misalnya saja film animasi untuk anak-anak, acara musik bagi remaja, segmen olah raga, tayangan berita, drama seri, liputan kuliner bagi yang suka makanan, travelling atau jalan-jalan, film action, menampilkan show/konser/pertunjukan dalam tayangan siaran langsung, dan masih banyak lainnya menambah deretan segmentasi yang tersedia yang hanya ada pada satu channel saja.

\footnotetext{
${ }^{14}$ Untuk data Commercial TV perhatikan sumber: Alo Liliweri, Komunikasi..., hlm. 534.
} 
Segmentasi tampak pada contoh acara televisi program yang ditujukan pada segmentasi penonton tertentu, misalnya program musik "Dahsyat" di RCTI yang tayang pada pukul 07.30-11.30 WIB Senin sampai Jumat, pukul 08.00 11.00 WIB pada Sabtu Minggu, ditujukan untuk kelompok penonton jenis kelamin laki-laki dan perempuan dengan rentang usia antara 15-24 tahun dengan kelas sosial ABC. ${ }^{15}$

Dalam periklanan segmentasi akan terlihat pada pesan iklan yang ditawarkan yaitu apakah produk/jasa/ide mengarah kepada penggunaan untuk kalangan tertentu. Apakah khusus diperuntukkan bagi wanita, laki-laki, anakanak, dewasa, lansia, dan sebagainya. Begitupun masing-masing kategori tersebut juga masih bisa dikotak-kotakkan lagi. Mulai dari segi usia tertentu, kesukaan/minat, dan banyak lagi yang lainnya. Maka produk/jasa/ide yang ingin ditawarkan melalui iklan tersebut akan disesuaikan menyasar kepada kategori yang telah ditentukan sebelumnya. Penentuan ini tentu diupayakan oleh pihak periklanan maupun pemasaran.

Urgensi dari pembagian audiens ke dalam segmentasi tertentu dalam periklanan sangat berarti. Bagi insan periklanan segmentasi penting dilakukan untuk mempermudah kegiatan periklanan. Pihak yang berkepentingan di bidang periklanan akan mudah mengeksekusi konsep periklanan ketika tahu segmentasi audiens yang disesuaikan terhadap produk/jasa yang ingin dilempar ke pasaran. Terlebih lagi dalam hal eksekusi pesan iklan akan disesuaikan dengan kategori kelompok audiens.

\section{Audiens sebagai Pembeli yang Potensial}

Pembeli yang potensial adalah istilah yang disebut oleh beberapa ilmuan, salah satunya adalah Winston Fletcher untuk menjelaskan kepada siapa sasaran pesan produk/jasa/ide yang terkandung dalam iklan ditujukan. ${ }^{16}$ Sekelompok orang ini berpotensi besar untuk mengkonsumsi produk/jasa yang ditawarkan

${ }^{15}$ Eric Harraman dalam Rusman Latief dan Yusiatie Utud, Siaran Televisi Nondrama: Kreatif, Produktif, Public Relations dan Iklan (Jakarta: Kencana, 2015), hlm. 51.

${ }_{16}$ Winston Fletcher, Advertising: A Very Short Introduction (New York: Oxford University Press Inc., 2010), hlm. 7. 
melalui iklan. Memang tidak bisa dipastikan apakah sekelompok orang yang disebut sebagai pembeli yang potensial ini akan menggunakan produk/jasa/ide yang ditawarkan melalui iklan namun besar kemungkinan adanya peluang bagi produk/jasa/ide tersebut akan dikonsumsi oleh mereka. Pembeli yang potensial dengan kata lain disebut sebagai target market atau sasaran pasar. Sesuai dengan namanya maka target market ini menunjukkan kemana iklan yang akan dikemas menyasar calon konsumennya.

Hal senada juga mempertegas nilai audiens sebagai pembeli yang potensial bahwa sasaran audiens yang dikategorikan tersebut menurut Agus S. Madjadikara memiliki parameter yang biasa disebut SES atau Socio Economic Strata yang didasarkan pada besarnya penghasilan dan belanja bulanan kelompok sasaran. ${ }^{17}$ Berangkat dari kategori yang didasarkan pada strata potensi daya beli ini, maka sasaran audiens kemudian dibagi lagi kedalam beberapa klasifikasi yang disebut sebagai segmentasi pasar.

Segmentasi pasar lebih sering dipakai ketimbang pendekatan tanpa segmentasi. Upaya ini menjadi cara terbaik untuk menjual ke pasar yaitu melalui perbedaan konsumen dan menyesuaikan strategi dan pesan periklanan berdasarkan perbedaan tersebut. Berdasarkan segmentasi pasar audiens diidentifikasi, dievaluasi, dan dipilih sebagai audiens sasaran, yaitu sekelompok orang dengan kebutuhan dan kerakteristik yang sama yang kemungkinan besar cocok untuk pasar dari produk pengiklan. ${ }^{18}$

Dari segmentasi pasar ini kemudian akan dipilih kembali sebagian audiens atau dikerucutkan kembali dalam jumlah yang lebih kecil untuk menentukan apa yang disebut sebagai target market. Berikut akan dipaparkan bagaimana target market diklasifikasikan ke dalam beberapa karakteristik.

\section{AUDIENS SEBAGAI TARGET MARKET DALAM PERIKLANAN}

Jika segmentasi berarti membagi pasar menjadi kelompok-kelompok orang yang memiliki karakteristik yang sama. Maka targeting berarti mengidentifikasi kelompok yang mungkin merupakan audiens yang paling

17 Agus S. Madjadikara, Bagaimana Biro Iklan Memproduksi Iklan (Jakarta: PT Gramedia Pustaka Utama, 2005), hlm. 31.

${ }^{18}$ Sandra Moriarty, dkk., Advertising..., hlm. 190. 
menguntungkan dan paling mungkin merespon pesan periklanan. ${ }^{19}$ Dua hal yang penting dalam upaya segmentasi untuk menghasilkan target market yang akurat adalah keinginan atau kebutuhan konsumen dan mengerti bagaimana membangun positioning produk pada target yang dituju. ${ }^{20}$

Target market atau sasaran pasar adalah istilah yang dikenal untuk menyebutkan sekelompok audiens yang telah ditentukan dalam segmentasi. Jadi, audiens sebagai target market akan tampak setelah audiens dibagi kedalam beberapa kategori berdasarkan segmentasi yang ada. Klasifikasi audiens sebagai target market berdasarkan segmentasi, yaitu terbagi ke dalam:

\section{a) Segmentasi Demografis:}

Segmentasi demografis pada dasarnya adalah segmentasi yang didasarkan pada peta kependudukan misalnya: usia, jenis kelamin, besarnya anggota keluarga, pendidikan tertinggi yang dicapai, jenis pekerjaan audiens, tingkat penghasilan, agama, suku dan sebagainya. ${ }^{21}$ Bersandarnya para pemasar terhadap karakteristik demografis ini karena mereka sering kali terkait erat dengan kebutuhan dan perilaku beli para konsumen serta dapat langsung diukur. ${ }^{22}$

Data demografi ini sangat dibutuhkan dalam menentukan strategi periklanan yang menyangkut bagaimana suatu produk dikomunikasikan kepada audiens sasaran atau target market. Ada baiknya pemasang iklan perlu memahami media-media apa saja yang dapat menjangkau segmen pasarnya, berapa anggaran yang dibutuhkan untuk menjangkau masing-masing segmen itu, kapan sebaiknya disiarkan dan siapa bintang iklan yang cocok untuk menjangkau setiap segmen. ${ }^{23}$

Usia adalah salah satu variabel dalam segmentasi demografis. Audiens dibedakan menurut usia anak-anak, remaja, dewasa, dan orang tua. Namun, pembagian ini masih terlalu luas, sebab kelompok usia dewasa memiliki rentang usia yang cukup luas sehingga perlu dibagi lagi menjadi kelompok-kelompok

\footnotetext{
${ }^{19}$ Ibid, hlm. 189.

${ }^{20}$ Irham Fahmi, Perilaku..., hlm. 51.

${ }^{21}$ Morissan, Periklanan: Komunikasi Pemasaran Terpadu (Jakarta: Kencana, 2010), hlm. 59.

${ }^{22}$ Monle Lee dan Carla Johnson, Prinsip-Prinsip Pokok Periklanan dalam Perspektif Global (Jakarta: Prenada, 2004), hlm. 90.

${ }^{23}$ Morissan, Periklanan..., hlm. 60.
} 
yang lebih kecil. Belch \& Belch sebagaimana dipaparkan oleh Morissan membagi segmentasi berdasarkan usia sebagai berikut:

\begin{tabular}{|c|c|}
\hline No. & Kelompok Usia \\
\hline 1 & $0-6$ tahun \\
2 & $6-12$ tahun \\
3 & $12-17$ tahun \\
4 & $18-24$ tahun \\
5 & $25-34$ tahun \\
6 & $35-49$ tahun \\
7 & $50-64$ tahun \\
8 & Di atas 64 tahun \\
\hline
\end{tabular}

Sumber: George E. Belch \& Michael A. Belch dalam Morissan, Periklanan:

Komunikasi Pemasaran Terpadu (Jakarta: Kencana, 2010), hlm.

61.

Sementara Biro Pusat Statistik (BPS) membagi audiens dan konsumen media massa berdasarkan usia yang dikelompokkan sebagai berikut:

\begin{tabular}{|c|c|}
\hline No. & Kelompok Usia \\
\hline 1 & $0-14$ tahun \\
2 & $15-20$ tahun \\
3 & $20-29$ tahun \\
4 & $30-39$ tahun \\
5 & $40+$ tahun \\
\hline
\end{tabular}

Sumber: Morissan, Periklanan: Komunikasi Pemasaran Terpadu (Jakarta: Kencana, 2010), hlm. 61. 
Jenis Kelamin merupakan variabel berikutnya dalam segmentasi demografis. Banyak produk menggunakan pendekatan jenis kelamin dalam membedakan audiens sebagai target market dalam periklanan. Ada satu brand produk yang ditujukan hanya kepada wanita atau hanya kepada pria. Isi media massa mempengaruhi audiens yang akan menggunakan media itu. Misalnya pada program acara televisi audiens laki-laki akan menyukai program olahraga atau berita sementara infotainment, sinetron, dan acara memasak lebih disukai audiens wanita. $^{24}$

Dilihat dari jenis kelamin dalam penyampaian pesan periklanan audiens sebagai target market akan menentukan kategori atau segmentasi sebuah produk. Dengan kata lain perusahaan pemilik produk/jasa/ ide menyediakan sebuah brand yang hanya fokus untuk kalangan tertentu dari segmentasi jenis kelamin ini. Lihat bagaimana produk shampo secara khusus menyasar wanita sebagai target market seperti Pantene, Sunsilk, TreSemme, Emeron, dan semacamnya. Sedangkan Clear for Men merupakan produk shampo yang khusus menembak audiens laki-laki sebagai target marketnya. Ada juga kategori produk yang menyasar untuk kedua jenis kelamin ini sebagai target marketnya hanya saja dibedakan dari segi varian. Semisal pembersih wajah yang menyasar target market keduanya antara lain Garnier. Shampo Clear sendiri juga menyediakan dua varian produk baik untuk wanita juga untuk laki-laki.

Pekerjaan juga termasuk variabel dari segmentasi demografis. Audiens yang memiliki pekerjaan tertentu umumnya suka mengonsumsi barang-barang tertentu yang berbeda dengan jenis pekerjaan lainnya. Dalam arti mereka punya selera sendiri. Pada umumnya selera mereka berbeda dalam mengonsumsi media massa. Kalangan eksekutif lebih suka media yang dapat mendorong daya pikir mereka atau membantu mereka dalam mengambil keputusan, misalnya menonton program berita atau film-film tertentu di televisi. Sementara kalangan pekerja kasar lebih menyukai musik dangdut. ${ }^{25}$

\footnotetext{
${ }^{24}$ Morissan, Periklanan..., hlm. 61.

${ }^{25}$ Ibid, hlm. 62.
} 
Pendidikan merupakan variabel berikutnya dalam segmentasi demografis dimana audiens dikelompokkan menurut tingkat pendidikan yang dicapai. Pendidikan yang berhasil diselesaikan biasanya menentukan pendapatan dan kelas sosial mereka. Selain itu pendidikan juga menentukan tingkat intelektualitas. Sehingga hal ini akan menentukan pilihan barang-barang, jenis hiburan, dan program radio atau televisi yang diikutinya. ${ }^{26}$

Biasanya tingkat pendidikan terkait pula dengan tingkat pekerjaan walaupun tidak selalu. Seorang yang berpendidikan tinggi cenderung membaca secara rutin surat kabar dan majalah-majalah tertentu sesuai dengan tingkat pendidikannya. Biasanya bacaannya agak berat, memerlukan pemikiranpemikiran dan analisis, menyukai konsep-konsep baru dan tertantang untuk menggali hal-hal baru. Sebaliknya, mereka yang hanya berhasil mencapai sekolah dasar umumnya akan mencari bacaan-bacaan yang ringan, mudah dipahami, banyak gambar atau foto, berjudul besar dengan permasalahan sehari-hari yang dekat dengan kehidupannya. ${ }^{27}$

Pendapatan termasuk juga sebagai variabel dalam segmentasi demografis. Audiens biasanya akan membeli atau menggunakan produk atau kebutuhannya sesuai dengan penghasilan yang diperolehnya. Selera atau pemenuhan kebutuhan hidup sangat dipengaruhi oleh kelas yang ditinggali oleh audiens tersebut. Variabel pendapatan ini akan menentukan kelas sosial dan kedudukan seseorang di dalamnya sekaligus mempengaruhi kemampuan seseorang untuk mengakses sumber-sumber daya. ${ }^{28}$

Perusahaan yang akan beriklan di radio atau televisi harus menentukan apakah ingin memasarkan produk untuk kalangan berpenghasilan tinggi, menengah, atau bawah. Media massa harus menegaskan kalangan mana yang menjadi targetnya sehingga pemasang iklan dapat mempromosikan produknya secara tepat. ${ }^{29}$

\footnotetext{
${ }^{26}$ Morissan, Periklanan..., hlm. 62.

${ }^{27}$ Ibid, hlm. 61-62.

${ }^{28}$ Ibid, hlm. 62.

${ }^{29}$ Ibid, hlm. 63.
} 
Beberapa konsep yang dijadikan tolak ukur dalam variabel pendapatan untuk melihat target marketnya adalah melalui ukuran penghasilan dalam bentuk uang tunai (money income) yang mencakup penghasilan dari gaji, keuntungan usaha, dividen, royalti, atau sumber-sumber lainnya yang diterima secara tunai sebelum dipotong pajak dan potongan-potongan lainnya. ${ }^{30}$

Agama juga menjadi variabel segmentasi demografis lainnya. Belakangan ini agama digunakan sebagai tolak ukur pengelompokan audiens sebagai target market dalam periklanan. Beberapa program acara misalnya yang bernuansa religius banyak mewarnai media massa. Lihat bagaimana sinetron religius, ceramah agama, dan sejenisnya banyak menyita perhatian audiens sebagai target market. $^{31}$

Begitu pun dalam periklanan dewasa ini banyak tampilan iklan yang dikemas dengan pertimbangan agama misalkan menampilkan nilai-nilai Islam sebagai indikator segmentasi audiensnya. Perhatikan kini banyak iklan yang menggaet bintang/model/tokoh iklannya berhijab menawarkan pesan periklanan baik melalui media massa ataupun secara langsung. Sebagaimana iklan produk Freshcare oleh Dewi Sandra berhijab, Malkist Cocola oleh Oki Setiana Dewi berhijab, Nippon Paint menampilkan Dian Pelangi berhijab, Luwak White Coffee oleh Laudya Chintya Bella berhijab dan masih banyak tampilan iklan lainnya yang menggunakan agama dalam hal ini adalah nilai-nilai Islam sebagai segmentasi pesan periklanan.

Ditambah lagi adakalanya citra produk itu sendiri tersegmentasi untuk menembak target market khusus untuk kalangan Islam. Disini nilai-nilai Islam dijadikan karakter produk yang ditawarkan dalam penyampaian pesan periklanan. Semisal produk Hi Lo Soleha yang jelas-jelas menyasar kaum muslimah sebagai target market yang ingin diterpa, deterjen Total juga tak mau kalah ikut menyasar target market para muslimah dengan menekankan unsur Halal pada kandungan produknya, Sunsilk Hijab juga fokus untuk audiens muslimah sebagai target marketnya, apalagi Wardah konsisten menangkap audiens kalangan muslimah

\footnotetext{
${ }^{30}$ Ibid, hlm. 63-64.

${ }^{31}$ Morissan, Periklanan..., hlm. 64.
} 
dengan mengusung tema Halal dan suci produknya dari kandungan yang dikhawatirkan. Dan masih banyak kategori agama yang dijadikan landasan untuk membagi audiens sebagai target market dalam periklanan.

Suku dan Kebangsaan juga termasuk kategori segmentasi demografis dalam membagi audiens sebagai target market. Disini audiens sebagai target market dibedakan berdasarkan kebiasaan-kebiasaan dan kebutuhan-kebutuhan yang mencolok dari suatu suku dibanding suku lainnya. Segmennya juga harus cukup besar, potensial, dan memliki daya beli yang tinggi. Biasanya suku-suku tertentu memiliki ciri khas dalam soal makanan, pakaian, dan cara berkomunikasi. $^{32}$

M. Suyanto mengurai sederet iklan yang memanfaatkan segmentasi demografis untuk menjangkau target market yang sesuai antara lain misalnya iklan Marlboro dari Philip Morris yang melakukan segmentasi pasar laki-laki. Iklan New BMW 5 Series produksi BBDO Roma berjudul 'Impossible' mencoba menyasar perhatian target market dari segmentasi pasar pendapatan tinggi. Dove dari Unilever melakukan segmentasi pasar kaum wanita dari iklan Dove shampoos and conditioners produksi oleh Ogilvy \& Mather. Ikea sendiri melakukan segmentasi target market anak-anak melalui iklan hasil kreasi CLM BBDO Swedia yang berjudul 'Table'. ${ }^{33}$

Lain lagi Coca-Cola, MTV, dan Swatch membidik pasar berdasarkan usia, yaitu remaja. Swatch membidik segmen remaja global berusia 12-24 tahun yang berorientasi pada mode, sedangkan Coca-Cola melakukan segmentasi pasar remaja dengan usia 15-21 tahun. Iklan televisi Exxon Mobil berjudul 'On the run' melakukan segmentasi pasar keluarga dimana iklan buatan DDB Worldwide ini mengintegrasikan 3 brand yang berbeda, yaitu Exxon, Esso, dan mobil di 63 negara. Iklan ini ditujukan pada kehidupan di jalan dan menekankan bahwa Exxon Mobil membantu membuat perjalanan lebih menyenangkan. ${ }^{34}$

\footnotetext{
${ }^{32}$ Ibid.

${ }^{33}$ M. Suyanto, Strategi Perancangan Iklan Televisi Perusahaan Top Dunia (Yogyakarta: CV. ANDI OFFSET, 2005), hlm. 7-11.

${ }^{34}$ M. Suyanto, Strategi..., hlm. 11-12.
} 


\section{b) Segmentasi Geografis:}

Audiens sebagai target market diperoleh berdasarkan jangkauan geografis atau wilayah tempat tinggal yaitu negara, provinsi, kabupaten, kota, sampai kepada lingkungan perumahan. Audiens terkadang memiliki kebiasan berbelanja yang berbeda-beda dipengaruhi lokasi dimana mereka tinggal. Para penganut segmentasi ini percaya setiap wilayah memiliki karakter yang berbeda dengan wilayah lainnya. Sehingga setiap wilayah di suatu negara perlu dikelompokkan berdasarkan kesamaan karakternya. ${ }^{35}$

Di Indonesia banyak produsen barang dan jasa fokus hanya di Pulau Jawa untuk penjualan produknya karena disinilah tinggal separuh penduduk Indonesia. Sehingga konsentrasi pembangunan yang lebih dipusatkan di Pulau Jawa mengakibatkan penduduknya memiliki daya beli yang lebih kuat dan relatif lebih mudah dijangkau oleh produsen yang berproduksi di Pulau Jawa. ${ }^{36}$

Coca-Cola memasarkan produk minuman dengan brand tertentu yang hanya dijual di Jepang yaitu Sokembicha (nonkarbonat, ginseng dan teh), Lactia (susu fermentasi), Aquarius (minuman untuk para atlet), Georgia (minuman kopi berkualitas), dan Qoo (minuman jus). Sony (perusahaan musik, elektronik, TV, game, dan film) hanya menjual produk elektronik tertentu di Jepang, seperti video games, alat penerjemah saku, dan barang-barang serupa. Kraft Foods memasarkan permen karet di Perancis, es krim di Brazil, pasta di Italia, dan saus di Jerman. ${ }^{37}$

\section{c) Segmentasi Geodemografis:}

Gabungan dari segmentasi geografis dengan demografis dimana audiens dalam kategori ini memiliki karakter-karakter geografis dan karakter demografis yang sama pula. Namun wilayah geografis harus sesempit mungkin, misalnya kawasan-kawasan pemukiman atau kelurahan. Sebagai contoh orang yang samasama tinggal di kawasan elit di suatu kota cenderung memliki karakteristik yang sama. Artinya mereka yang tinggal di daerah elit dan memiliki karakter yang berbeda dengan mereka yang bertempat tinggal di kawasan perkampungan. ${ }^{38}$

\footnotetext{
${ }^{35}$ Morissan, Periklanan..., hlm. 64-65.

${ }^{36} \mathrm{Ibid}$, hlm. 65.

${ }^{37}$ M. Suyanto, Strategi..., hlm. 5.

${ }^{38}$ Morissan, Periklanan..., hlm. 65.
} 


\section{d) Segmentasi Psikografis:}

Pada segmentasi ini audiens dibagi berdasarkan gaya hidup dan kepribadiannya. Gaya hidup mempengaruhi perilaku, dan akhirnya menentukan pilihan-pilihan konsumsi audiens. Antara seorang wanita karier dan seorang ibu rumah tangga tentu saja memiliki gaya hidup yang berbeda yang pada akhirnya mempengaruhi bagaimana mereka membelanjakan uang mereka. Gaya hidup mencerminkan bagaimana seseorang menghabiskan waktu dan uangnya yang dinyatakan dalam aktivitas-aktivitas, minat dan opini-opininya. Dengan demikian, psikografis mengelompokkan audiens secara lebih tajam daripada sekedar variabel demografi. ${ }^{39}$

Ada delapan segmen gaya hidup masyarakat perkotaan di Indonesia sebagai berikut: (1) Kelompok Sejahtera/15 \% yaitu pekerja keras, memiliki rasa percaya diri yang kuat, menyukai inovasi, proaktif, dan berani mengambil resiko; (2) Kelompok Sukses/14 \% yaitu audiens yang mengonsumsi barang-barang secara fungsional. Pengambilan keputusan berdasarkan rasional; (3) Pencemas/6 $\%$ yaitu audiens sebagai pengikut, tetapi ambisius. Rasa percaya diri yang kuat, memerlukan saran dan dorongan dari orang lain, mudah dibujuk dengan hal yang sifatnya rasional; (4) Penyendiri/10\% yaitu senang menyendiri dan kurang berani untuk tampil, cenderung individualis dan kurang tertarik untuk bertetangga atau berteman; (5) Kelompok Gaul/11\% yaitu senang bergaul, bersosialisasi dengan orang lain, cenderung menguasai orang lain, dan senang menonjol, reaktif terhadap perubahan dan cenderung bersifat impulsif; (6) Pendorong/6 \% yaitu orang yang tidak ingin diperhatikan tetapi ingin mendominasi segala sesuatu tanpa arah yang jelas. Tidak memiliki objektif yang jelas untuk meraih sesuatu tetapi senang mengontrol orang lain namun tidak mudah menerima hal-hal yang baru; (7) Pencari Perhatian/17\% yaitu audiens yang cenderung ingin menarik perhatian, senang membeli barang-barang baru untuk menarik perhatian orang lain, impulsif, dan sering kali rasional, cenderung mudah dibujuk secara emosional dan cenderung mengikut (8) Pencari Kesenangan/20\% yaitu audiens yang ingin

\footnotetext{
${ }^{39}$ Ibid, hlm. 64-65.
} 
mencapai sesuatu tanpa kerja terlalu keras, cenderung individualistis, kurang senang bersosialisasi, tetapi tekun mengikuti tren. ${ }^{40}$

Dari kedelapan segmentasi tadi tampaknya cukup jelas bahwa bagian terbesar masyarakat perkotaan Indonesia cenderung mencari kesenangan (37\% gabungan dari segmen pencari kesenangan dan pencari perhatian). Pasar Indonesia terbagi dua secara merata antara segmen high profile (49\%) dan low profile $(51 \%)$. Para pemasar dapat memilih segmen gaya hidup mana yang hendak disasar. $^{41}$

Ilustrasi dari pemanfaatan segmentasi psikografis untuk menetapkan target marketnya adalah sebagaimana yang digambarkan oleh M. Suyanto misalnya American Express mengeluarkan Blue American Express dengan segmentasi pasar gaya hidup modern. Dell Computer melakukan segmentasi pasar pada kepribadian dengan menampilkan pelayan Dell yang berkepribadian penuh gairah dalam melayani pembeli yang dibuat oleh DDB Worldwide. Stanford Research Institute (SRI) membuat sebuah model yang disebut VALS (Value and LyfestyleS) dan disempurnakan menjadi VALS2, yang mengkombinasikan faktor demografi dan gaya hidup ke dalam delapan kelompok yaitu fulfiller, beleiver, achiever, striever, experiencer, maker, strugler, dan actualizer. ${ }^{42}$

Fulfiller adalah target market yang rata-rata berusia 48 tahun, matang, bertanggung jawab, mempunyai pendidikan profesional yang baik, dan berorientasi pada nilai. Believer adalah audiens yang rata-rata berusia 58 tahun, konservatif, dan menyukai brand yang telah mapan. Achiever rata-rata berusia 36 tahun, sukses, dan berorientasi pada pekerjaan yang memuaskan pekerjaan dan keluarganya. Striever adalah yang berusia rata-rata 34 tahun, sumber ekonomi, sosial, dan psikologisnya lebih rendah. Maker adalah mereka yang rata-rata berusia 30 tahun, praktisi, merupakan konsumen yang fokus pada keluarga, pekerjaan, dan rekreasi fisik. Struggler adalah berusia rata-rata 61 tahun pendapatan rendah dan sumber daya terbatas, serta berorientasi pada dirinya

\footnotetext{
${ }^{40}$ Morissan, Periklanan..., hlm. 66-68.

${ }^{41}$ Ibid, hlm. 68.

${ }^{42}$ M. Suyanto, Strategi..., hlm. 16.
} 
sendiri. Actualizer rata-rata berusia 43 tahun pendapatan paling tinggi, kebanggan diri sangat kuat, dan memiliki sumber daya melimpah. ${ }^{43}$

Contoh audiens yang berasal dari segmen psikografis lainnya adalah dengan menggunakan kepribadian. Kepribadian brand disesuaikan dengan kepribadian audiens sebagai target marketnya. Pembeli Chevrolets bercirikan kepribadian konservatif, hemat, memperhatikan harga diri, kurang maskulin, dan berusaha untuk tidak menjadi ekstrem. Pembeli Ford mempunyai ciri independen, tanggap terhadap perubahan dan percaya diri. ${ }^{44}$

\section{Audiens adalah Target Market}

Setelah audiens dibagi ke dalam kelompok-kelompok tertentu berdasarkan segmentasi yang telah dipaparkan sebelumnya maka selanjutnya audiens yang tersegmentasi tersebut dipilih kembali untuk ditentukan sebagai target market yang dituju dalam upaya penyampaian pesan periklanan agar pesan tersebut tepat sasaran. Fokus hanya pada target yang dituju saja, sehingga upaya periklanan menjadi mudah.

Menurut Morissan target market adalah memilih satu atau beberapa segmen audiens yang akan menjadi fokus kegiatan-kegiatan periklanan baik dalam pemasaran maupun promosi. Adakalanya targeting disebut juga dengan selecting karena audiens harus diseleksi terlebih dahulu. Perusahaan harus berani memfokuskan kegiatannya pada beberapa bagian saja (segmen) audiens dan meninggalkan bagian yang lainnya. ${ }^{45}$

Target audiens berhubungan erat dengan adanya media yang dapat digunakan untuk menjangkau kelompok-kelompok atau segmen-segmen tertentu dalam masyarakat. Target market mempunyai dua fungsi sekaligus, yaitu menyeleksi audiens sasaran sesuai dengan kriteria-kriteria tertentu dan menjangkau audiens sasaran tersebut. ${ }^{46}$

Pada prakteknya ketika pesan periklanan menyasar target market yang telah ditentukan, maka audiens sebagai target market tadi mengalami selective

\footnotetext{
${ }^{43}$ M. Suyanto, Strategi..., hlm. 16.

${ }^{44}$ Ibid.

${ }^{45}$ Morissan, Periklanan..., hlm. 70.

${ }^{46}$ Ibid, hlm. 71.
} 
exposure terlebih dahulu. Yaitu tahapan dimana audiens tadi secara aktif memilih mau atau tidak mengekspos dirinya terhadap informasi yang diberikan melalui iklan yang menerpanya. Jadi, sekalipun perusahaan melakukan promosi dengan membabi buta kepada audiens apakah melalui televisi misalnya, maka audiens akan menyeleksi benar-benar dalam bentuk mau atau tidak ia menerima informasi produk/jasa itu. Jika audiens tidak mau menerima informasi tersebut mungkin ia akan memindahkan channel televisi atau meninggalkan televisi menuju ke kamar kecil atau mengajak rekannya berbicara di saat iklan ditayangkan. Kalau ini yang terjadi maka informasi tadi tidak akan diproses oleh audiens tersebut dan menguap begitu saja. Maka hanya orang yang memiliki minat dan keinginan untuk mengekspos program atau iklan yang menerpa dirinya itulah yang disebut sebagai target market yang dipilih berdasarkan segmentasi yang ada. ${ }^{47}$

Target market atau sasaran pasar dalam periklanan akan tampak pada kategori berdasarkan varian produk/jasa yang akan ditawarkan kepada mereka. Ada relevansi antara produk dengan kategori audiens sebagai target market yang ingin ditembak. Misalnya saja, pada kalompok produk shampoo maka audiens yang dimaksud sebagai target marketnya adalah umumnya wanita. Namun adakalanya produk dari varian yang sama dimana selama ini menyasar target market wanita menggesernya atau pun menambah segmentasinya yaitu laki-laki. Lihatlah produk pembersih wajah yang selama ini fokus kepada target market wanita kini melebarkan pangsa pasar sasarannya yaitu laki-laki sebagai target market sekaligus bertambah konsentrasi fokus sasaran pasarnya. Misalkan Garnier Men, Nivea Men, Vaseline Men, Pond's Men, Men's Biore, dan lainnya dimana tadinya produk-produk ini tersegmentasi khusus untuk wanita, namun kini variannya bertambah ditandai dengan penambahan istilah men pada brandnya sekaligus mengindikasikan bahwa target market produk ini berdinamika dengan kata lain menunjukkan adanya peningkatan.

Lebih lanjut Sandra Moriarty, dkk menjelaskan adanya istilah profil dalam proses menentukan audiens sebagai target market dalam periklanan. Setelah audiens dibagi berdasarkan segmentasi yang ada kemudian audiens tadi dibuat

\footnotetext{
${ }^{47}$ Morissan, Periklanan..., hlm. 71-72.
} 
profilnya berdasarkan informasi deskriptif dari faktor demografis dan psikografis sebagaimana telah disebutkan semula. Sebagai contoh, seperti apa faktor usia, pendapatan, pendidikan, geografi, dan psikografis dari audiens selaku konsumen? Maka profil merupakan deskripsi target market yang dipakai untuk mempersonalisasikan audiens sebagai konsumen dalam rangka memilih media sasaran dan pesan. ${ }^{48}$

Profil target market digunakan untuk mempersempit mereka ke dalam bagian-bagian terkecil untuk memudahkan kegiatan periklanan/pemasaran. Semakin kecil kelompok target market maka upaya periklanan/pemasaran ini bisa lebih fokus/intens. Metodenya dilakukan dengan menyusun profil yang diawali dengan karakteristik yang paling penting. Misalkan produk popok bayi (diaper), maka target market dari produk ini adalah ibu-ibu. Tentu profil dari mereka ini berbeda-beda, sebagian ibu-ibu adalah orang kaya sementara yang lainnya biasa saja. Maka perkecil lagi golongan kelompok ibu-ibu ini ke dalam karakteristik terpenting seperti berdasarkan gender kemudian usia sehingga menjadi wanita usia 18-35 tahun. Berikutnya tambahan faktor pendapatan, orang kota/desa, pendidikan, atau faktor lainnya sebagai upaya untuk mempersempit audiens sehingga menjadi target market yang tepat sekaligus mempersempit target market $^{49}$ sebagaimana ditunjukkan oleh gambar berikut:

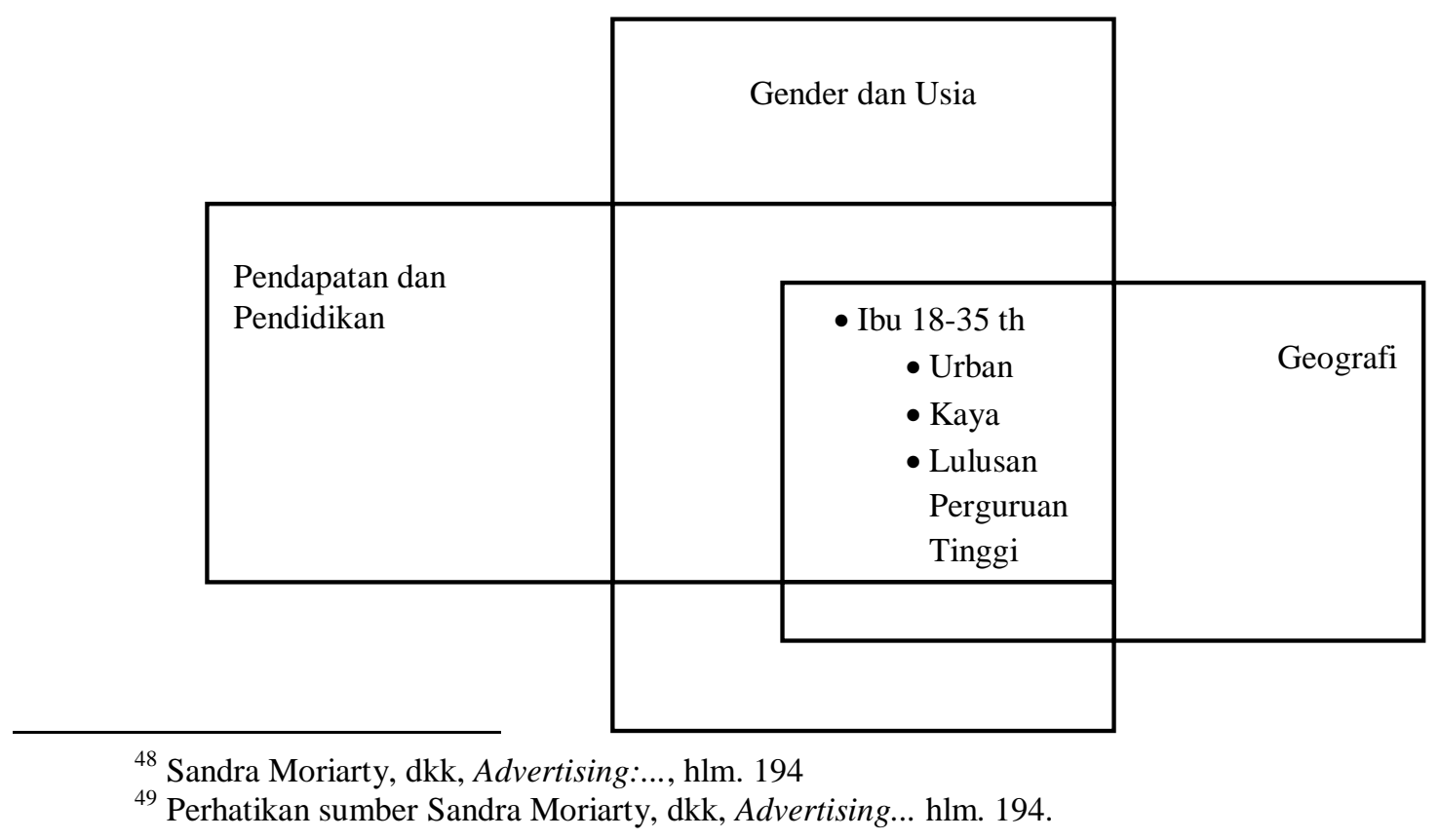


Sumber: Sandra Moriarty, dkk, Advertising: Edisi Kedelapan (Jakarta: Kencana. h. 195.

\section{Audiens Sebagai Komunikan Islam}

Saat ini perhatian dunia terhadap Islam semakin besar. Diawali dengan meningkatnya pertumbuhan muslim di beberapa wilayah, eropa misalnya. ${ }^{50}$ Pesatnya pertumbuhan ini berimbas kepada sektor bisnis, perindustrian, dan semacamnya yang tak lain juga berpengaruh terhadap periklanan. Sehingga muslim sebagai komunikan Islam menjadi target market yang patut diperhitungkan. Sebagaimana Shelina Janmohamed menuturkan kondisi tersebut dalam bukunya bahwa muslim pada era ini menjadi sasaran pasar yang potensial dimulai dari fashion, kuliner, pelayanan kesehatan juga pariwisata dan lainnya. Selain itu segala hal yang berkaitan dengan ekonomi berbasis Islam juga mulai dilirik ditandai dengan brand, rancangan/konsep bisnis, produk, dan sejenisnya menjadi kiblat baru bagi sektor tersebut. ${ }^{51}$

Ini mengindikasikan bahwa audiens sebagai komunikan Islam menjadi barometer untuk memasukkan unsur/nilai-nilai Islam ke dalam periklanan. Komunikan Islam menjadi generasi muslim yang layak dipertimbangkan sebagai acuan konsep periklanan. Banyaknya tokoh/bintang/model iklan yang menggunakan hijab saat menyampaikan pesan periklanan tidak hanya melalui media televisi melalui billboard juga dan media lainnya ikut menyemarakkan suasana bahwa komunikan Islam sebagai audiens khususnya dalam periklanan sedang menjadi target market yang tersegmentasi khusus dalam pertimbangan agama sebagai unsur demografisnya.

\footnotetext{
50 Perhatikan sumber: Jaya Suprana, Fenomena Londonistan (Pertumbuhan Islam di Eropa), $\quad$ http://www.portal-islam-.id/2017/04/fenomena-londonistan-pertumbuhanislam.html?m=1, diakses tanggal 02 November 2017, pukul 00:22 WIB, juga sumber: Panji Islam (Rep) dan Cholis Akbar (editor), Uskup Agung Italia Sebut Eropa Bakal Jadi Negara Islam, http://m.hidayatullah.com/berita/internasional/read/2017/01/17/109840/uskup-agung-italia-sebuteropa-bakal-jadi-negara-islam.html, diakses tanggal 02 November 2017, pukul 00:30 WIB.

51 Lihat sumber Waspada, Shelina Janmohamed Tulis Buku Tren Konsumerisme Muslim, Edisi Minggu 13 November 2016/14 Safar 1438 H; No:25464 Tahun ke-68 hlm. B10.
} 
Belum lagi dengan pencantuman label Halal dari suatu Badan/Majelis yang diberikan kewenangan untuk menyeleksi berbagai macam produk/barang yang beredar di pasaran, menjadi unsur tambahan sebagai acuan lain dalam periklanan. Lihatlah beberapa produk dalam iklannya menawarkan unsur Halal untuk produknya. Misalnya Wardah, shampo Hijab, deterjen Total, minyak kayu putih Fresh Care, makanan ringan Malkist Cocola, Suplemen/multivitamin Natur $E$, dan masih banyak lainnya.

Perlu digarisbawahi pada kondisi ini dimana audiens sebagai komunikan Islam menjadi pasar potensial yang mendapatkan pesan periklanan melalui media apa saja, sehingga sudah sepatutnya mampu mengembangkan daya kognisi bukan daya konsumsi agar mampu membedakan antara kebutuhan dan keinginan dalam menggunakan produk/jasa.

Sebagaimana gempuran produk/ jasa sedang menghimpit dewasa ini. Apalagi dalam dunia periklanan begitu banyak dan beragam distribusi produk/jasa yang ditawarkan. Menambah referensi untuk berbelanja kebutuhan hidup. Bermacam-macam produk dengan brand yang bermacam-macam pula bahkan dari produk yang sejenis sekalipun kehadirannya semakin hari semakin bermunculan.

Ditambah hadirnya beberapa supermarket mini di sekitar tempat tinggal lengkap dengan tampilan yang menarik mata belum lagi beberapa pusat perbelanjaan (mall) yang berdiri dengan megahnya. Maka, jika individu tidak mampu menggunakan daya kognisi dan daya konsumsinya dengan benar maka dikhawatirkan ini berpotensi menumbuhkan sikap konsumtif atau bahkan lama kelamaan bisa mengarah kepada perilaku konsumtif. Dimana seseorang membeli banyak/beberapa produk yang ditawarkan kepadanya tanpa adanya pertimbangan rasional. Antara kebutuhan dan keinginan menjadi bias. Jika kondisi ini berlarut, maka dikhawatirkan komunikan Islam khususnya sebagai audiens yang telah diterpa sederet iklan akan berpotensi menjadi shopaholic yaitu hasil dari perilaku konsumtif. Istilah yang digunakan untuk menyebutkan orang yang suka sekali membelanjakan sejumlah uangnya untuk membeli barang/produk yang belum tentu dibutuhkan tanpa pertimbangan rasional. 
Dalam Islam sikap konsumtif mengarah kepada berlebih-lebihan (Boros) atau nama lainnya adalah mubazir, jelas Allah melarang perbuatan ini. Perhatikan firman Allah SWT :

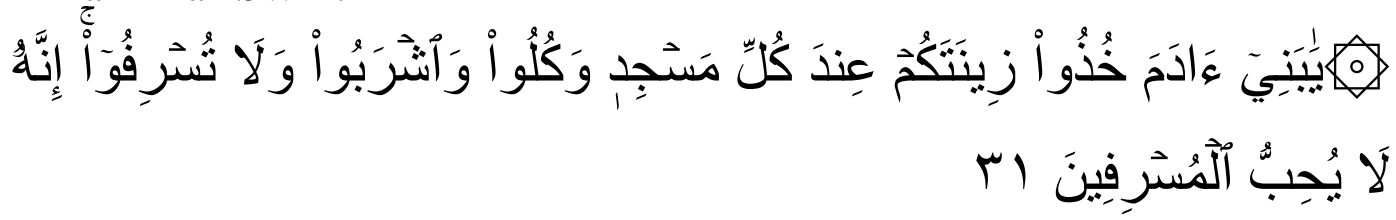

31. Hai anak Adam, pakailah pakaianmu yang indah di setiap (memasuki) mesjid, makan dan minumlah, dan janganlah berlebih-lebihan. Sesungguhnya Allah tidak menyukai orang-orang yang berlebih-lebihan. (QS. Al-A'Raf: 31$)^{52}$

Untuk menghindari hal ini, maka audiens sebagai komunikan Islam hendaknya harus memiliki karakter aktif bukan pasif. Dalam arti mestilah mampu membedakan mana kebutuhan mana keinginan diantara beragam produk/jasa yang berada di tengah kehidupannya.

Apalagi ketika mendapatkan terpaan iklan yang bertubi-tubi, seorang muslim harus mampu memilih mana iklan yang menawarkan produk/jasa yang sesuai dengan kebutuhan. Dengan kata lain muslim dituntut untuk bisa selektif ketika pesan iklan menerpa dirinya dalam hal memilah produk yang akan digunakan/dikonsumsi. Bukan menjadi audiens pasif yang langsung menerima bahkan langsung menggunakan produk yang ditampilkan melalui iklan tanpa adanya pertimbangan secara logis. Dimulai dari harga, ketersediaan, efektivitas produknya, sampai kepada kebutuhan akan produk tersebut. Banyak hal yang harus dijadikan catatan ataupun penilaian ketika dirinya diterpa beragam pesan iklan. Maka audiens sebagai komunikan Islam sepatutnya memiliki kontrol terhadap dirinya untuk bisa memprioritaskan antara kebutuhan dan keinginan.

Belum lagi pertimbangan khas ditinjau dari aspek nilai-nilai Islam yaitu kewajiban untuk mengkonsumsi bahan yang memiliki unsur Halal di setiap kandungan/bahan produk yang ditawarkan, menuntut komunikan Islam wajib sadar dan teliti dalam mengkonsumsi ataupun merujuk setiap produk atau segala

\footnotetext{
${ }^{52}$ Al-Qur'an in Ms Word version 2.2.0.0. 2013 oleh Mohamad Taufiq.
} 
sesuatu yang ditawarkan melalui pesan periklanan yang menerpa diri komunikan Islam tersebut selaku ummat muslim.

Alhasil, sekali lagi audiens sebagai komunikan Islam hendaknya semakin mampu mengembangkan daya produktif untuk kemajuan ummat. Selama beberapa tahun terakhir hanya sebagai objek sasaran atau dengan kata lain konsumtif semata, namun kini seiring perkembangan zaman silih berganti, sekarang generasi muslim juga sudah bisa unggul dalam prestasi menghasilkan karya yakni melibatkan diri dalam sektor periklanan baik sebagai modelnya maupun insan kreatifnya namun juga di sektor lain turut andil dalam melahirkan busana bahkan tersegmentasi pada fashion muslimah secara global. ${ }^{53}$

\section{Penutup}

Audiens sebagai target market dalam periklanan memiliki hubungan erat dengan segmentasi yang disediakan baik oleh media ataupun pihak produsen pemilik produk. Media menyediakan beragam ruang atau segmen yang disesuaikan dengan audiens yang akan menerima pesan tersebut. Sementara di bidang periklanan, target market disesuaikan berdasarkan kategori produk yang menyasar mereka. Maka tak heran jika audiens sebagai target market dalam periklanan memiliki cakupan yang lumayan luas, tidak hanya sebatas merujuk kepada siapa pesan periklanan itu dilancarkan namun ditambah adanya proses pemilihan audiens sebagai target market dalam upaya ini.

\footnotetext{
${ }^{53}$ Perhatikan sumber: Dailymoslem.com. Indonesia International Islamic Fashion Fair: Gelaran Fashion Muslim Internasional Pertama Dari Indonesia, http://m.dailymoslem.com/news/indonesia-international-islamic-fashion-fair-gelaran-fashionmuslim-internasional-pertama-dari-indonesia-, diakses tanggal 24 Oktober 2016 pukul. 21:13 WIB, sumber lain: Khoiri, Agniya. CNN Indonesia, Busana Muslim dan Efek Bola Salju Muffest 2016, http://m.cnnindonesia.com/gaya-hidup/20160519195411-277-132073/busana-muslim-danefek-bola-salju-muffest-2016/, diakses tanggal 14 April 2017 Pukul 00:57 WIB serta masih banyak sumber lainnya.
} 


\section{DAFTAR PUSTAKA}

Al-Qur'an in Ms Word version 2.2.0.0. 2013 oleh Mohamad Taufiq.

Dailymoslem.com. Indonesia International Islamic Fashion Fair: Gelaran Fashion Muslim Internasional Pertama Dari Indonesia. http://m.dailymoslem.com/news/indonesia-international-islamic-fashionfair-gelaran-fashion-muslim-internasional-pertama-dari-indonesia-. Diakses tanggal 24 Oktober 2016 pukul. 21:13 WIB.

Effendy, Onong Uchjana. 2013. Ilmu Komunikasi: Teori dan Praktek. Bandung: PT Remaja Rosdakarya.

Fahmi, Irham. 2016. Perilaku Konsumen: Teori dan Aplikasi. Bandung: Alfabeta.

Fletcher, Winston. 2010. Advertising: A Very Short Introduction. New York: Oxford University Press Inc.

Ibrahim, Idi Subandy. 2007. Kecerdasan Komunikasi. Bandung: Simbiosa Rekatama Media.

Islam, Panji (Rep) dan Cholis Akbar (editor). Uskup Agung Italia Sebut Eropa Bakal Jadi Negara Islam. http://m.hidayatullah.com/berita/internasional/read/2017/01/17/109840/u skup-agung-italia-sebut-eropa-bakal-jadi-negara-islam.html. Diakses tanggal 02 November 2017, pukul 00:30 WIB.

Khoiri, Agniya. CNN Indonesia, Busana Muslim dan Efek Bola Salju Muffest 2016. http://m.cnnindonesia.com/gaya-hidup/20160519195411-277132073/busana-muslim-dan-efek-bola-salju-muffest-2016/. Diakses tanggal 14 April 2017 Pukul 00:57 WIB.

Latief, Rusman dan Yusiatie Utud. 2015. Siaran Televisi Nondrama: Kreatif, Produktif, Public Relations dan Iklan. Jakarta: Kencana.

Lee, Monle dan Carla Johnson. 2004. Prinsip-Prinsip Pokok Periklanan dalam Perspektif Global. Jakarta: Prenada.

Liliweri, Alo. 2011. Komunikasi Serba Ada Serba Makna. Jakarta: Kencana.

Madjadikara, Agus S. 2005. Bagaimana Biro Iklan Memproduksi Iklan. Jakarta: PT Gramedia Pustaka Utama.

Moriarty, Sandra, Nancy Mitchell, dan William Wells. 2011. Advertising: Edisi Kedelapan. Jakarta: Kencana.

Morissan. 2010. Periklanan: Komunikasi Pemasaran Terpadu. Jakarta: Kencana. 
Suprana, Jaya. Fenomena Londonistan (Pertumbuhan Islam di Eropa), http://www.portal-islam-.id/2017/04/fenomena-londonistanpertumbuhan-islam.html?m=1. Diakses tanggal 02 November 2017, pukul 00:22 WIB.

Suyanto, M. 2005. Strategi Perancangan Iklan Televisi Perusahaan Top Dunia. Yogyakarta: CV. ANDI OFFSET.

Vivian, John. 2008. Teori Komunikasi Massa: Edisi Kedelapan. Jakarta: Kencana.

Waspada. Shelina Janmohamed Tulis Buku Tren Konsumerisme Muslim. Edisi Minggu 13 November 2016/14 Safar 1438 H; No:25464 Tahun ke-68 hlm. B10.

Widyatama, Rendra. 2009. Pengantar Periklanan. Yogyakarta: Pustaka Book Publisher.

Nama: Tengku Walisyah

Tempat /Tanggal Lahir : Lubuk Pakam/01 Juni 1984

Pekerjaan: Dosen Fakultas Dakwah dan Komunikasi UIN-SU Medan 